ROCZNIKI TEOLOGICZNE

Tom LXVI, zeszyt 9 - 2019

DOI: http://dx.do.org/10.18290/rt.2019.66.9-6

JACEK JAN PAWLIK SVD

\title{
RELIGIA PRZEŻYWANA
}

\section{LIVED RELIGION}

\begin{abstract}
A b s t r a c t. The article presents the concept of a lived religion, which corresponds to modern forms of experiencing the sacred. Postmodernity emphasizes religious experience, often individual, apart from institutionalization of churches. The concept of a lived religion complies with new forms of the sacred stressing, among others, the meaning of embodiment, discourse, materiality and sensational forms in religious experiences. The concept of a lived religion focuses on a person practicing religion, however, ignoring the issues of transcendence, truth and supernatural effects.
\end{abstract}

Key words: Religion; Postmodernity; Experience; Emotions.

Termin „religia przeżywana” (lived religion) pojawił się około trzydzieści lat temu w Stanach Zjednoczonych jako ekwiwalent terminu ,religia codzienności” (everyday religion). Kryje się pod nim określona koncepcja religii, a przede wszystkim program badawczy. Przyjmuje się, że po raz pierwszy użyto tego terminu w tytule książki Lived Religion in America pod redakcją Davida Halla, która była pokłosiem konferencji zorganizowanej przez Harvard Divinity School w 1994 roku. Konferencja ta zgromadziła głównie historyków zajmujących się badaniami życia codziennego laikatu protestanckiego.

Obecność historyków w początkowym etapie badań religii przeżywanej (codzienności) nie jest zadziwiająca, tym bardziej że to właśnie z kręgu histo-

Dr hab. Jacek Jan PAWLIK SVD, prof. UWM - Katedra Nauk o Rodzinie, Wydział Teologii UWM w Olsztynie; adres do korespondencji: Wydział Teologii UWM, ul. St. Hozjusza 15, 11-041 Olsztyn; e-mail: jacek.pawlik@uwm.edu.pl 
ryków pochodzi gros prac dotyczących życia codziennego. „Życie codzienne - pisze Roch Sulima - to zawsze pewien historyczny, praktykowany sposób życia, typ kultury, którego konceptualizację i opisy znajdziemy w pracach historyków” (Sulima, 2017, s. 6). Sulima jednak odróżnia „życie codzienne” od „codzienności”, społecznego wymiaru życia, który wyraża się w cielesności, emocjach, działaniach i w stylu życia (Sulima, 2017, s. 6). Z czasem w badaniach religii przeżywanej daje się zauważyć przejście od prac historycznych życia codziennego do bardziej socjologicznych lub antropologicznych studiów na temat codzienności oraz przesunięcie akcentu z poszukiwania modeli i struktur religii na to, co aktualnie przeżywają ludzie religijni. Innym ważnym aspektem codzienności, który wyraża się w pojęciu religii przeżywanej, jest pewien egalitaryzm wywodzący się z tradycji badań codzienności. Chodzi o codzienne myślenie i działanie zwykłych ludzi, w przypadku zaś religii przeżywanej, chrześcijan lub wyznawców innych religii. Badania interesuja się tym, co na polu religijnym dzieje się poza wspólnotą kościelną i uznaja obok kleru i specjalistów rytualnych laikat za pełnoprawnych aktorów społecznych. Religia przeżywana dotyczy więc życia codziennego zwykłych ludzi przeżywających religię na swój sposób, a nie tego, co dzieje się w scenerii zinstytucjonalizowanego życia religijnego.

Wprowadzenie pojęcia religii przeżywanej - zgodnie z zamierzeniem Davida Halla - miało na celu przezwyciężenie binarnej opozycji między religią oficjalną a religijnością ludową. Koncepcja ta odrzuca rozróżnienie religia elitarna - religia popularna, które narzuca się samo przez się w badaniach religijności ludowej. Religia ludowa - zdaniem tego autora - znaczyła przestrzeń na styku między oficjalnym lub uczonym chrześcijaństwem a kulturą świecką (,,pogańską”). W przestrzeni tej świeccy mężczyźni i kobiety cieszyli się pewnym stopniem autonomii. Stawali się niezależnymi aktorami kształtującymi (lub przekształcającymi) praktyki religijne w zgodności z lokalnymi warunkami (Hall, 1997, s. VIII). Dotyczyło to przede wszystkim zwyczajów dorocznych ściśle związanych z przeżywaniem świąt religijnych lub okazyjnych naznaczających etapy rozwoju jednostki. Kreatywność w oprawie i przeżywaniu wydarzenia spoczywała więc na barkach osób świeckich.

Wprowadzenie pojęcia religii przeżywanej pozwala odrzucić rozróżnienie elitarny/ludowy i mówić o „wspólnej religii” - wychodząc od doświadczenia religijnego jednostki. W rzeczy samej omawiana koncepcja kładzie akcent na

\footnotetext{
${ }^{1}$ Mówienie o „wspólnej religii” aż nadto przypomina postulat „wspólnej kultury” Raymonda Williamsa w ramach tzw. studiów kulturowych (Williams, 1958).
} 
sprawczość indywidualną i autonomię jednostki bardziej niż na autorytet wspólnoty czy tradycji. Prowadzi to do wolności wyboru praktyk uważanych za spersonalizowane, często zhybrydyzowane pod względem treści. Praktyki te sytuują się poza instytucjami religijnymi, nawet jeśli niewiele odbiegają od kanonu, nie odwołują się do niego ani nie szukają oficjalnego potwierdzenia. W tym kontekście kwestia wierzenia spychana jest na dalszy plan, jeśli nie jest po prostu negowana. Nie stawia się pytania o transcendentną instancję odniesienia, ale kładzie się akcent na aktualną praktykę i subiektywne jej skutki. Religia przeżywana, rozumiana jako sposób, w jaki religia jest osadzona w życiu codziennym, odrzuca instytucjonalność oraz elitarność i nie uznaje autorytetu religijnego. Jest religią laikatu, niesformalizowaną religijnością zwykłych ludzi.

Religię przeżywaną daje się zdefiniować najlepiej przez to, czym nie jest. Kładzie ona nacisk na codzienne praktyki sakralizacji, które mogą, ale nie muszą pokrywać się z przyjętą oficjalnie definicją sacrum. Wychodzi od człowieka religijnego i pomijając doktrynę koncentruje się na sytuacjach, które zgodnie z tradycją nie są uważane za religijne, a które w oczach konkretnych ludzi takie znaczenie posiadają. Jak wspomniano, religia przeżywana koncentruje się na praktyce religijnej. Nie chodzi tu o przyjmowanie sztucznego podziału na religię zorganizowaną i życie codzienne. Nawet jeśli praktyki religijne są „,codzienne”, rzadko oddalają się od instytucji i tradycji religijnych, przynajmniej jeśli chodzi o ich formę. Niemniej, samo działanie instytucji religijnych nie jest brane pod uwagę.

Nancy T. Ammerman (2016) przeprowadziła analizę 64 artykułów, opublikowanych w języku angielskim w latach 1997-2016, dotyczących religii przeżywanej. W wyniku tych badań stwierdza, że kładą one głównie nacisk na praktykę, która wyraża się w wymiarach ucieleśnienia, dyskursu i materialności. Krótkie przedstawienie tych trzech aspektów pozwoli na głębsze zrozumienie koncepcji religii przeżywanej.

Od lat 70. XX wieku ciało ludzkie stało się ważnym przedmiotem badań w antropologii kulturowej jako symbol i wyrażenie ludzkiej kultury. W religii przeżywanej przyjęto koncepcję ucieleśnienia, która neguje tradycyjny sposób pojmowania człowieka jako dychotomię duszy i ciała. Zakłada ona, że ucieleśnienie (embodiment) jest egzystencjalną podstawą kultury. Obejmuje ono całą sferę zmysłowości w przeżywanym doświadczeniu. Ponieważ w pierwotnych przeżyciach religijnych zmysłowość odgrywa istotną rolę, ucieleśnienie jest kluczowym składnikiem doświadczeń religijnych. Koncepcja ucieleśnienia została rozwinięta przez Thomasa Csordasa (1990; 1994), który nie uzaje ciała za przedmiot, który powinno się badać w powiązaniu z kulturą, ale za 
podmiot kultury, ponieważ ciało odgrywa centralną rolę w procesie jej powstawania. Stąd nie tylko ciało jest naznaczone kulturą, ale również kultura jest rezultatem obiektywizacji, który rozpoczyna się w ciele i od niego wychodzi. Proces ten nazywa Csordas ucieleśnieniem (bodily aspects of human subjectivity). Nie stawia sobie za cel badania samego procesu, ale pragnie z tej perspektywy zrozumieć zasady, na których wyrasta kultura.

Koncepcja ucieleśnienia bazuje na pracach Maurice'a Merleau-Ponty'ego i Pierre'a Bourdieu. Zgodnie z Merleau-Ponty kultura jest rezultatem procesu postrzegania, który zaczyna się w ciele i kończy na kulturowych obiektach. Percepcja zaczyna się w ciele. Nie ma przedmiotów poza percepcją, ponieważ są one drugorzędnym produktem refleksyjnego myślenia. Merleau-Ponty postuluje płaszczyznę subiektywnego doświadczenia, które nie zna jeszcze żadnych zdeterminowanych obiektów, ale które przez reagowanie ciała ma już kulturowe znaczenie. Ponieważ ciało i kultura warunkują się wzajemnie, ciało może coś obiektywizować, tzn. spostrzec coś poza sobą, kiedy jest siebie świadome, a może nazywać siebie tylko wtedy, kiedy dostrzeże świat społeczny poza sobą ${ }^{2}$.

Drugim autorem, do którego odwołuje się Csordas, jest Pierre Bourdieu (2007), którego prace sugerują, że praktyki cielesne, usytuowane w habitusie, pośredniczą między jednostką a społeczeństwem. To właśnie habitus jest zbiorem praktyk jako system trwałych dyspozycji, który jest nieświadomą, zbiorowo przekazywaną zasadą. Miejscem habitusu jest koniunkcja między obiektywnymi warunkami życia a całością aspiracji i praktyk dostosowanych do warunków. W społecznie ustrukturyzowanym świecie, przez naśladownictwo i stałe schematy koncepcyjne, ciało uczy się klasyfikowania własnej kultury. W ten sposób generuje schematy, które go naznaczyły. Wiedza kulturowa jest przekazywana z ciała na ciało. Habitus to nic innego jak społecznie naznaczone ciało. Habitus proponuje ponadindywidualne dyspozycje, które używają ciała, aby odnaleźć się w świecie społecznym i wiedzieć, jak ono sensownie działa dostosowane do społecznego porządku. ,Jako uniwersalizująca mediacja habitus ma podwójną funkcję. W relacji do obiektywnych struktur jest zasada generowania praktyk, natomiast w relacji do całkowitego repertuaru społecznych praktyk, jest ich unifikującą zasadą" (Csordas, 1990, s. 12).

Religia przeżywana kładzie nacisk na praktykę. Jeśli więc przyjmiemy, że rzeczy święte są tworzone i dzielone przez ludzi, będziemy poszukiwać wyra-

\footnotetext{
${ }^{2}$ Csordas, odwołując się do „Fenomenologii percepcji” Merleau-Ponty’ego, wychwytuje m.in. następujące definicje ciała: „ustawienie wobec świata” (Merleau-Ponty, 2001, s. 327) i „ogólna możność zamieszkiwania wszystkich środowisk świata” (Merleau-Ponty, 2001, s. 336).
} 
zów cielesnych i namacalnych oddźwięków, które te praktyki kształtują. Położenie akcentu na ucieleśnienie nadaje przeżyciom religijnym znaczenie bazujące na fizycznych, emocjonalnych i estetycznych odczuciach. Takie podejście jest możliwe tylko wtedy, kiedy odrzuci się pojmowanie religii jako relacji i skupi się na biegunie ludzkim jako twórcy i wypełnieniu religii.

Zwrócenie uwagi na dyskurs przyczyniło się do rozwoju przeżywanej teologii (lived theology). Trzeba rozróżnić teologię jako dogmat lub doktrynę od teologii jako codziennej praktyki lub działania społecznego. Teologia przeżywana może być uprawiana tylko we wspólnocie. Jest to bowiem proces, wprowadzenie w czyn tego, co jest najbardziej dla ludzi religijnych znaczące, w każdym momencie, jako przeżycie ludzkiej egzystencji, bardziej niż systematyzacja propozycji Credo jakiejkolwiek tradycji wiary. Tradycyjnie teologię uważa się za dyscyplinę akademicką, interpretującą uznane za autentyczne źródła. Przeżywana teologia łączy się z tradycjami egzystencjalnymi, empirycznymi i fenomenologicznymi, które uznają boskość jako zjawisko doświadczenia. W prezentacji teologii przeżywanej w Internecie (www.livedtheology. org/overview/) czytamy: „Jesteśmy przekonani, że wzory i praktyki religijnych wspólnot oferują bogaty i twórczy materiał dla badań teologicznych. Wzory te i praktyki nie sa po prostu sposobami 'robienia rzeczy', ale są też sposobami 'mówienia o rzeczach', praktyki i wzory są 'komunikatywne'. Jako teologowie i badacze religii wierzymy, że przeżywane doświadczenia wiary, jeśli są właściwie interpretowane, są komunikatywne nie tylko dla samozrozumienia kolektywu religijnej wspólnoty, ale również dla modułów boskiej obecności”.

Dzielenie się więc doświadczeniem religijnym nadaje religii przeżywanej charakter społeczny. Poza zwróceniem uwagi na cielesność i rolę zmysłów badania w zakresie religii przeżywanej podkreślają i analizują to, co się mówi. Istotą jest słuchanie tego, w jaki sposób zwykli ludzie nadają znaczenie przeżyciom religijnym. Dyskursywne praktyki, takie jak opowiadanie, śpiew i pisemne sformułowania, mają moc przekonywania, trafiają na pozytywny oddźwięk w społecznych kontekstach, w których żyją ludzie.

Lansując antropologię „szczegółu” Albert Piette podkreśla znaczenie przekonań religijnych poszczególnych osób. „Zharmonizowanie wierzeń jednostki $\mathrm{z}$ wyobrażeniami publicznymi otoczenia lub uporządkowanymi $\mathrm{w}$ formie ortodoksji i wyrażenie ich w spójnej wyjątkowości kulturowej prowadzi do odwrócenia bezpośredniego spojrzenia od zachowań i konkretnych działań" (Piette, 2015, s. 231). Inaczej mówiąc jest to poddanie wypowiedzi wzbogaconych uczuciami i przeżyciami zmysłowymi pod cenzurę ortodoksji oraz niedopuszczenie lub ignorowanie wariantów indywidualnych, a przecież 
w przeżyciach religijnych występują zarówno chwile euforii jak i zwątpienia, co wyraża się często w formie dyskursywnej. „Fakt religijny, czy byłby to rytuał, aktywność codzienna lub wierzenie, jest zawsze przeniknięty grą negacji zmuszającą aktorów do ciągłego ruchu i zajęcia charakterystycznego miejsca "pomiędzy'" (Piette, 2003, s. 13). Wsłuchiwanie się w to, jak wierni wyrażają w słowach swe przekonania religijne pozwala na uchwycenie dynamiki wierzenia, które oscyluje wokół akceptacji, zwątpienia i negacji. Podobne podejście nie doczekało się zbyt wielu opracowań naukowych.

Trzeci aspekt religii przeżywanej, na jaki wskazują analizy Nancy Ammerman, dotyczy materialności. Wpisuje się ona w lansowany $\mathrm{w}$ antropologii zwrot ku rzeczom, który zwracając uwagę na materialność, stawia sobie za cel analizę możliwych zastosowań i działań rzeczy. Rzeczy miałyby być jedynie narzędziem w rękach człowieka służącym do zaspokojenia jego potrzeb. W przypadku religii przeżywanej podkreśla się sakralizację rzeczy i miejsc. Doświadczenie religijne może być osadzone we wszystkim, od ubioru i biżuterii, po ulubiony fotel przy oknie. „Miejsca i rzeczy są kluczowym wymiarem religii przeżywanej, sposobem, w jaki ludzie dosłownie dotykają transcendencji. [...] Ta rzecz lub to miejsce uczestniczyło w tworzeniu, spotkaniu lub dzieleniu się czymś świętym w życiu. Uważna analiza tego, jak działa świat kultury materialnej, będzie ważnym komponentem badań religii przeżywanej" (Ammerman, 2016, s. 14). Ponadto należy dodać, że istotnym czynnikiem wpływającym na stosunek do rzeczy jest pamięć. Pozytywne skojarzenia moga nadać niektórym przedmiotom aurę świętości.

Koncepcja religii przeżywanej jest pewnego rodzaju odpowiedzią na ,paradygmat sekularyzacji” rozumiany ogólnie jako perspektywa teoretyczna zakładająca upadanie lub osłabienie religii w społeczeństwach nowoczesnych. Paradygmat $w$ tym pierwotnym znaczeniu od wielu lat kwestionują socjolodzy religii, m.in. Peter L. Berger (2005), Thomas Luckmann (2012) czy Janusz Mariański (2013). Wskazują oni na przemieszczanie się sacrum i powstawanie nowych form religii poza instytucjami kościelnymi. Pośród tych głosów warto wspomnieć świetny esej Rogera Bastide'a Dzika świętość wydany w zbiorze pod tym samym tytułem w 1975 roku. Autor stwierdza, że głoszona śmierć ustanowionych bogów nie pociąga za sobą z konieczności zniknięcia stanowiącego doświadczenia świętości. Jego zdaniem kryzys organizacji religijnych pochodzi z braku odpowiedniości między wymaganiami osobistego doświadczenia religijnego a ramami instytucjonalnymi. U młodego pokolenia jesteśmy świadkami dokonującego się z pasją poszukiwania świętości, „tak jakby nasi współcześni, po dość długim okresie rozwoju ateizmu lub tylko zdania się na indyferentyzm, uświadomili sobie na nowo, że istnieje w ich wnętrzu ko- 
nieczna do wypełnienia pustka duchowa i stwierdzili na bazie tego odczucia pustki, że osobowość, która nie jest zakorzeniona w pewnego rodzaju świętym entuzjazmie, jest w ostateczności osobowością pozbawioną tego, co stanowi powszechny i stały wymiar antropologiczny dla każdego człowieka przeżywającego religijność" (Bastide, 2008, s. 23).

Zwracając uwagę na religijność, jako antropologiczny wymiar człowieka, Bastide jakby intuicyjnie potwierdza naturę homo religiosus i wynikająca z niej potrzebę przeżywania religii, niemniej jako socjolog analizuje jej praktykę nie wypowiadając się o jej istocie. Tak jak nowoczesność w ramach odczarowania świata i kultu sekularyzacji głosiła zastąpienie religii przez ideały postępu, takie jak przedłużenie życia, maksymalizację zdrowia, wyrugowanie bólu i poprawę warunków materialnych dzięki nowym technologiom i wzrostowi gospodarczemu, tak ponowoczesność promuje rodzaj religii, która „opuściła" kościoły i instytucje, by stać się przeżyciem pełniącym ważne znaczenie w życiu ludzkim, które jednak stroni od struktury. Religia ponowoczesności odpowiada na kluczowe potrzeby egzystencjalne: nadanie sensu cierpieniu i bolesnej stracie oraz chwilom egzaltacji, powiązanie kruchości życia z poszukiwaniami duchowymi czy rytualizacja trudnych przejść. Nawiązuje do mitów i starych wierzeń, do magicznych wyobrażeń dzieciństwa, do niezwykłych opowiadań o zaginionych cywilizacjach. Dystansuje się od chrześcijaństwa kwestionując jego wyłączność i poszukuje inspiracji w innych religiach świata. Jest religia życia codziennego kładąc nacisk na przeżycia osoby religijnej i jej doświadczenia intymne. Odpowiada na potrzebę zaradzenia rozdarciom, jakie niesie z sobą nieszczęście i śmierć. Nie mogąc ich zanegować, podmiot religijny ucieka się do rytualizacji i symbolizacji, aby odnaleźć równowagę (Jeffrey, 1998, s. 9-11). Ponowoczesność religijna daje człowiekowi możliwość uznania religii za podstawowy czynnik relacji do siebie samego, do innych i do środowiska życia.

Religia ponowoczesności jest wieloraka i niestała. Ponieważ nie ma trwałych punktów odniesienia ani specjalistów kontrolujących interpretację tekstów, ani obowiązku moralnego przynależności do określonego wyznania, stwarza pewną lukę, która faworyzuje indywidualne poszukiwania odpowiedzi na pytania dotyczące religii. Rzadko jednak prowadzi do spotkania z transcendencją, zaś najczęściej ogranicza się do praktyki, która rytualizuje ważne zdarzenia życia, aby ułatwić ich przyjęcie oraz chronić od związanego z nimi lęku. Koncepcja religii przeżywanej wychodzi naprzeciw tym zmaganiom współczesnego człowieka na polu religijności. Uznając charakter indywidualny doświadczeń religijnych, zatrzymuje się na jej wyrazie emocjonalnym i na poziomie materialności. 
Długoletnia badaczka kultur i religii Zachodniej Afryki, Birgit Meyer (2009), proponuje oryginalną koncepcję religii przeżywanej, kładąc nacisk na estetyczny wymiar doświadczenia religijnego oraz formy mediacyjne sacrum. Tego typu podejście ma swoje źródło w pracach wielu poprzedników. Warto w tym miejscu cofnąć się do eseju Victora W. Turnera Dewey, Dilthey i gra społeczna: szkic z zakresu antropologii doświadczenia (Turner, 2011), w którym autor definiuje estetykę w następujący sposób: „Estetyka to zatem te fazy istnienia danej struktury czy procesualnej jednostki przeżycia, które albo stanowią spełnienie sięgające głębi istoty tego, kto doświadcza (jak to ujmował Dewey), albo tworzą niezbędne trudności i niedostatki prowadzące do radosnej walki, by osiągnąc spełnienie wykraczające poza rozkosz i równowagę, prawdziwą radość i szczęście urzeczywistnienia" (Turner, 2011, s. 49). Dla Turnera do doświadczeń typu estetycznego należą bez wątpienia przeżycia religijne, których fazą kulminacyjną byłby, drogi dla tego autora, stan communitas.

Trzeba podkreślić, że autorzy, łączący doświadczenie z doznaniami estetycznymi, przyjmują szerokie pojęcie estetyki. I tak redaktorzy cennego tomu Aesthetics in Performance wyjaśniają: „Nasze pojęcie estetyki stosuje się do stworzonych symbolicznych gatunków lub dynamicznych struktur, ukonstytuowanych lub wyłonionych przez ludzkie doświadczenia, znaczenia i wartości" (Hobart, Kapferer, 2005, s. 1). Sztuka nie jest więc ostatecznym wyrazem estetyki, natomiast estetyka jest tym, co łączy sztukę z życiem. Podejście estetyczne pozwala odkryć dynamikę sił kryjących się poza ludzkim kulturowym i historycznym doświadczeniem. Bo w końcu, żyjące rzeczywistości bytu ludzkiego są już symbolicznymi tworami, w których ukierunkowane jest wszelkie działanie (Hobart, Kapferer, 2005, s. 5).

Birgit Meyer również przyjmuje szerokie pojęcie estetyki jako pełne doświadczenie zmysłowe świata oraz wiedzę o nim odwołując się do „aisthesis” Arystotelesa. Ufa, że takie rozumienie estetyki pozwala lepiej wyrazić afektywną moc obrazów, dźwięków i tekstów (Meyer, 2009, s. 6). Uważa, że konieczne jest odwołanie się do tak szerokiego pojęcia estetyki, aby uchwycić wyobraźnię, szczególnie w sferze religii. „Wyobrażenia te, choć artykułowane i formowane przez media, wydają się być usytuowane poza mediacją dokładnie dlatego, że są wcielane i ucieleśniane, a przez to przywołują i uwieczniaja dzielone doświadczenia, emocje i afekty w nich zakorzenione, jak też sprowokowane przez uznany za oczywisty światopogląd, świat rzeczywistego zdrowego rozsądku" (Meyer, 2009, s. 7).

Odwołując się do estetyki, Birgit Meyer stara się przezwyciężyć - jej zdaniem - destruktywne rozróżnienie między duchem a materią i uchwycić 
materialny wymiar religijnych sposobów formowania podmiotów i wspólnot (Meyer, 2009, s. 10). Religię najlepiej zrozumieć jako praktykę mediacji. Autorka stosuje jednak szerokie pojęcie mediów, zaliczając do nich: film, radio, fotografię, telewizję, komputer, ale też kadzidło, zioła, zwierzę ofiarne, ikony czy święte miejsca. „Transcendencja nie jest czymś, co się objawia, ale jest wynikiem procesu mediacji” (Meyer, 2009, s. 11). „Byty ludzkie, jako żyjące ciała, mają zdolność do transcendencji, do wyjątkowej eksterioryzacji bytu, która sytuuje nas 'gdzie indziej' i 'inaczej', nawet jeśli jest zakorzeniona i związana z naszym żyjącym tu i teraz ciałem” (Meyer, 2009, s. 27).

Autorka wprowadza pojęcie „formy czuciowe”. Są to stosunkowo trwałe, przyjęte sposoby wzywania i organizowania dostępu do transcendencji. Przekazywane i dzielone stwarzają i utrzymują więzy między wierzącymi. Form czuciowych nie należy traktować w przeciwieństwie do treści i znaczenia lub do etycznych norm i wartości. Są one koniecznym warunkiem, bez którego treści i moralność nie mogą być przekazywane. Formy czuciowe można określić jako kondensację praktyk związanych z postawami i ideami, które strukturyzują religijne doświadczenie. Działają w kontekście poszczególnych tradycji, które przywołują odczucia przez pobudzenie szczególnych dyspozycji (Meyer, 2009, s. 13).

Formy czuciowe, wykorzystujące narzędzia estetycznej mediacji, są nieodzownym komponentem przeżyć religijnych, i bynajmniej nie chodzi tutaj o przeżycia indywidualne, ale wspólnie przeżywane rytuały lub widowiska religijne. $\mathrm{Z}$ pewnością duży wpływ na ich formę będzie miała kulturowa koncepcja ciała oraz wrażliwość zmysłowa pielęgnowana w danej kulturze. Na przykład afrykańską skłonność do tańca, jako formę wyrazu przeżyć religijnych, można tłumaczyć specyficznym zmysłem równowagi, o którym pisze odnośnie do ludu Ewé Kathryn Linn Geurts (Geurts, 2008, s. 7-8). Analiza Birgit Meyer zatrzymuje się na praktykach religijnych. Jako antropolog kulturowy stwierdza otwarcie człowieka na transcendencję, nie wypowiadając się o niej. Kiedy jednak nie przyjmie się wiary w istnienie Boga u praktykujących ludzi, ich aktywność na polu religijnym traci podstawowy sens.

W książce Religia przeżywana. Katolicyzm i jego konteksty we wspótczesnej Ghanie Anna Niedźwiedź przedstawia życie religijne mieszkańców parafii Jama. Praca oparta na badaniach terenowych stanowi wnikliwą analizę praktyk religijnych tamtejszych katolików. Przyjmując schemat religii przeżywanej, nakreślony przez Birgit Meyer, autorka stosuje charakterystyczny aparat pojęciowy: formy czuciowe, formacje estetyczne, wiedza ucieleśniona, wielozmysłowość, materialność doświadczenia religijnego i mediacyjność. Przyjęcie schematu religii przeżywanej pozwala jej na zawarcie w jednym schemacie 
pojęciowym religii katolickiej i afrykańskich religii tradycyjnych. Ujęcie religii, jakie proponuje Niedźwiedź, wpisuje się w pole religijności, praktyk związanych z przeżyciami bez względu na rodzaj religii. Chodzi o praktyki, w których zaangażowane jest ciało w takim stopniu, że pozwala podkreślić jego wyjątkowość, szczególnie jeśli chodzi o zmysłowość. Praca krakowskiej etnolożki pokazuje silną potrzebę religii u badanych mieszkańców. Istotną rolę odgrywa tu tradycja. Po pierwsze jest to tradycja, jaką tworzy codzienność bazująca na modelu chrześcijańskim. Po drugie, jest to wciąż bardzo żywa tradycja przodków przedchrześcijańskich, tym bardziej, że chrześcijaństwo przybyło do Ghany zaledwie w połowie XIX wieku. Tradycja ta w postaci działań i zachowań symbolicznych odgrywana jest równolegle lub w powiązaniu z praktykami chrześcijańskimi. Istnieją bowiem takie zobowiązania rytualne, których zaniedbanie grozi niebezpieczeństwem choroby lub innych nieszczęść. Chodzi tu o pewne czynności związane z ciałem, na przykład ryty oczyszczenia i separacji związane z żałobą. Ich znaczenie jest tak wielkie, że muszą być przeprowadzone nawet po upływie dłuższego czasu dla spokoju sumienia i ku zadowoleniu krewnych.

Praca Niedźwiedź pokazuje, że koncepcja religii przeżywanej pozwala na ukazanie praktyk człowieka religijnego nie wchodząc zbyt głęboko w treści wyznawanej doktryny i w ortodoksję wierzeń. Decyzja o podjęciu czynności rytualnych tradycyjnych wynika z presji społecznej środowiska niechrześcijańskiego, przywiązania do dawnych zwyczajów czy lęku przed ewentualnymi konsekwencjami niepoddania się wymogom tradycji. Większość współczesnych nie zastanawia się nad sprzecznością wierzeń tradycyjnych z wyznawaną doktryną chrześcijańską. Pewne zwyczaje należy po prostu przestrzegać. Koncepcja religii przeżywanej niweluje problem synkretyzmu, stawiając w centrum religijności formy czuciowe i formacje estetyczne, akcentuje przeżycie, spychając na dalszy plan lub wręcz ignorując kwestię odniesień doktrynalnych.

Czy łączenie tradycji religijnych na bazie przeżyć mogłoby być punktem wyjścia do dialogu międzyreligijnego? W punkcie wyjścia rodzi się pytanie dotyczące samego pojęcia religii. Być może należałoby mówić jedynie o religijności, o religii spontanicznej, o której pisze Henri Maurier, a która wynika z aktywności biologicznej przeżywanej na ludzki sposób (Maurier, 1997, s. 36). Niemniej praktyka religijna nabiera w pełni sensu tylko w odniesieniu do transcendencji, do tego, co wykracza poza byt ludzki. Łączenie na bazie wyboru lub konieczności tradycji religijnych i praktyk symbolicznych jest możliwe tylko wtedy, kiedy zredukuje się wartości religijne do sfery prywatności, „etniczności”, odmawiając im miejsca pośród wartości uniwersalnych. Aby mówić o religii w pełni praktykowanej, trzeba sięgnąć do tradycji danej 
religii. To nie praktyki dostosowane do zmieniającego się świata pozwalają na głębokie przeżycie religijne, ale zakotwiczenie w tradycji, świadomość, że religia była praktykowana $\mathrm{w}$ takiej a takiej formie od stu- a nawet tysiącleci oraz przekonanie o prawdzie przekazanej i uprawomocnionej przez autorytety religijne. Subiektywizm religii przeżywanej nie dopuszcza pytania o prawdę obiektywną. Kryteria bowiem skuteczności tak rozumianej religii mają charakter utylitarystyczny. Jeśli zaś religia ma drugorzędne znaczenie dla człowieka, a każdy może wybierać, co uważa za stosowne z każdej tradycji, dialog międzyreligijny nie jest potrzebny.

Mimo podkreślania doświadczenia indywidualnego koncepcja religii przeżywanej nie wyklucza odwołania się do tradycji. Nawet jeśli tzw. zwykli ludzie dobierają praktyki z różnych źródeł religijnych, które na poziomie doktrynalnym są niekompatybilne, czerpią głównie z tradycji, w której zostali wychowani, która jest najbliższa ich wspomnieniom i do której mają wyraźny stosunek emocjonalny. Czy to będą wyznawcy którejś denominacji protestanckiej, katolicy europejscy lub afrykańscy, będą oni czerpać praktyki z tego, co im najbliższe, swojskie formy czuciowe i formacje estetyczne. Tradycja pochodzenia będzie też wyznacznikiem tożsamości religijnej.

Religia przeżywana, która jest faktem we współczesnym świecie, jest wyzwaniem dla każdej ortodoksji. Nie stawia pytania o prawdę, działanie Boże czy odniesienie do transcendencji. Liczy się przeżycie religijne, indywidualnie lub w grupie, spychając na dalszy plan kwestię Credo. Jest szczególnym zagrożeniem dla Kościołów, ponieważ przemilcza problem autorytetu, hierarchii czy sukcesji. Organizacje religijne powinny sobie postawić pytanie o sposoby skanalizowania przeżyć religijnych wyznawców, by zaowocowały odnową i dodały dynamizmu wspólnotom religijnym. Bastide pisał, że sacrum opuściło Kościoły, ale być może chodzi o ludzi religijnych, którzy praktykują poza Kościołami. Sytuacja taka nie może trwać długo. Człowiek to nie tylko homo religiosus, ale również homo socialis. W związku z tym tworzy się pole do działania dla uzdolnionych liderów przygarniających ludzi poszukujących nowych przeżyć religijnych, o czym świadczą mnożące się sekty. 


\section{BIBLIOGRAFIA}

Ammerman, Nancy T. (2016). „Lived Religion as an Emerging Field. An Assessment of Its Contours and Frontiers". Nordic Journal of Religion and Society, 29(2), 83-99. Https://hdl. handle.net/2144/19161 (dostęp: 3.01.2019).

BASTIDE, Roger (1975). „Le sacré sauvage”. W: TENŻE. Le sacré sauvage et autres essais (s. 214-236). Paris: Payot. Tłum. polskie Jacek J. Pawlik, „Dzika świętość”. Konteksty. Polska Sztuka Ludowa, 62(2008), 1:23-31.

Berger, Peter L. (2005). Święty baldachim. Elementy socjologicznej teorii religii. Kraków: Zakład Wydawniczy NOMOS. Pierwodruk 1967.

BoURDIEU, Pierre (2007). Szkic teorii praktyki poprzedzony trzema studiami na temat etnologii Kabylów. Kęty: Wyd. Marek Drzewiecki. Pierwodruk 1972.

Csordas, Thomas J. (1990). „Embodiment as a Paradigm for Anthropology”. Ethnos, 18/1, 5-47.

TENŻE (1994). „Introduction. The Body as representation and being-in-the-world”. W: Embodiment and experience. The Existential ground of culture and self. Red. Thomas J. Csordas (s. 1-24). Cambridge: Cambridge University Press.

GEURTS, Kathryn Linn (2008). „O kamieniu, chodzeniu i mówieniu w Afryce Zachodniej. Kategorie kulturowe i antropologia zmysłów”. W: Estetyka Afryki. Antologia. Red. Małgorzata Cymorek (s. 5-26). Kraków: Universitas.

HaLl, David (1997). „Introduction”. W: Lived Religion in America. Toward a History of Practice. Red. David Hall (s. VII-XIII). Princeton: Princeton University Press.

Hobart, Angela, KAPFERER, Bruce (2005). „Introduction. The Aesthetics of Symbolic Construction and Experience". W: Aesthetics in Performance. Formations of Symbolic Construction and Experience. Red. Angela Hobart, Bruce Kapferer (s. 1-22). New York: Berghahn Books.

JEFFREY, Denis (1998). Jouissance du sacré. Religion et postmodernité. Paris: Armand Colin.

LuCKMAnN, Thomas (2012). Niewidzialna religia. Problem religii w nowoczesnym społeczeństwie. Kraków: Zakład Wydawniczy NOMOS.

MARIAŃSKI, Janusz (2013). Sekularyzacja. Desekularyzacja. Nowa duchowość. Studium socjologiczne. Kraków: Zakład Wydawniczy NOMOS.

MAURIER, Henri (1997). La religion spontanée. Philosophie des religions traditionnelles d'Afrique noire. Paris: L'Harmattan.

MERLEAU-PPONTY, Maurice (2001). Fenomenologia percepcji. Warszawa: Aletheia. Pierwodruk 1945.

MeYER, Birgit (2009). „Introduction. From Imagined Communities to Aesthetic Formations: Religious Mediations, Sensational Forms, and Styles of Binding”. W: Aesthetic Formations. Media, Religion, and the Senses. Red. Birgit Meyer (s. 1-28). New York: Palgrave Macmillan.

NiEDźwIEDŹ, Anna (2015). Religia przeżywana. Katolicyzm i jego konteksty we wspótczesnej Ghanie. Kraków: Wyd. Libron.

PIETTE, Albert (2003). Le fait religieux. Une théorie de la religion ordinaire. Paris: Economica.

PIETTE, Albert (2015). „Fakt religijny. Zwyczajna teoria religii”. Przeł. Jacek J. Pawlik. Forum Teologiczne, 16, 223-245.

Sulima, Roch (2017). „'Upadek’ w codzienność”. Konteksty. Polska Sztuka Ludowa, 71, (1-2): 6-9.

TURNER, Victor W. (2011). „Dewey, Dilthey i gra społeczna: szkic z zakresu antropologii doświadczenia”. W: Antropologia doświadczenia. Red. Victor W. Turner, Edward M. Bruner (s. 43-54). Kraków: Wyd. UJ. Pierwodruk 1986.

WiLliams, Raymond (1958). Culture and Society. London: Chatto and Windus.www.livedthe ologiy.org/overview/ (dostęp: 24.01.2019). 


\section{RELIGIA PRZEŻYWANA}

St r e s z c z e n i e

Artykuł przedstawia koncepcję religii przeżywanej, która odpowiada współczesnym formom przeżywania sacrum. Ponowoczesność kładzie nacisk na doświadczenie religijne, często indywidualne, poza instytucjonalizacją kościołów. Koncepcja religii przeżywanej wychodzi naprzeciw nowym formom sacrum podkreślając m.in. znaczenie ucieleśnienia, dyskursu, materialności i form czuciowych w doświadczeniach religijnych. Koncepcja religii przeżywanej koncentruje się na człowieku praktykującym religię, jednak pomija kwestie transcendencji, prawdy i skutków nadprzyrodzonych.

Słowa kluczowe: religia; ponowoczesność; doświadczenie; emocje. 